\title{
24 \\ The role of Hindu and Muslim organizations during the 2006 election
}

\section{Jonathon Prasad ${ }^{1}$}

On the walls of many Fiji Indian households, next to pictures of Hindu deities, hangs the photograph of Mahendra Chaudhry. Routinely garlanded whenever pujas (religious ceremonies) are performed, the image depicts a leader often cast in the role of saviour, deity and martyr. Transcending the realm of politics and entering into mythology, Chaudhry evokes the role of King Rama in the Ramcaritmanas, a popular Sanatan religious text; a good, just ruler banished from his kingdom and forced to wander in the wilderness enduring numerous trials at the hands of raksas (demons) until he is permitted to return home and take up his rightful place on the throne. The tragedy of Labour's rise and fall between 1999 and 2001, and the righteousness of its cause at the 2006 poll seemed to mimic Hindu mythology. On the campaign trail, Fiji Labour Party (FLP) candidates appealed to the symbolism of Hinduism, weaving marigold garlands normally used for prayer and laying these at the feet of elders whilst touching their feet as a traditional sign of respect.

The relationship of Hindu and Muslim symbolism to the politics of Fiji needs to be seen in the broader context of the relations between the migrantdescended and indigenous Fijian communities. Nearly all ethnic Fijians are Christian, whereas the Fiji Indian population is approximately 76.7 per cent Hindu, 15.9 per cent Muslim and 6.1 per cent Christian. ${ }^{2}$ The Christian churches in Fiji, in particular the Methodist Church, have often been associated with a virulent brand of Fijian nationalism, including calls for the country to 
become a 'Christian state'. ${ }^{3}$ The governing Soqosoqo Duavata ni Lewenivanua (SDL) party's manifesto explicitly paid homage to 'the ideals and principles of the Christian faith'. ${ }^{4}$ As with minority religious groups elsewhere in the world, Hindu and Muslim religious leaders have, unsurprisingly, responded by emphasizing the importance of secular politics, the importance of distance between faith and state, and their own lack of strong ties to any of the major political parties. In addition, the collectively felt pressures on the Indian community in the wake of the coups of 1987 and 2000 have emphasized the need for a common front, and diminished political articulation of internal cultural difference. As a result, the influence of religious organizations and symbolism on the Indian community has become more subtle, nuanced and indirect - on balance, lessening in favour of a greater engagement with educational advancement.

The way in which Indian religious organizations influence the political process has changed over the past two decades along with the culture of politics in Fiji. Previously, charismatic political leaders linked to religious organizations could count on the support of the leadership of those organizations and, in turn, the votes of their members. Voting was based on religious affiliation as much as on political persuasion. The events of 1987 did much to alter the political landscape, with religious groups becoming increasingly self-conscious of their activities and public profile. This led them to adapt their strategy and sphere of influence to a more focused approach, targeting education as a specific policy issue, as it is an area in which they have a vested interest.

This is not to say that communal voting is no longer relevant for both IndoFijians and Fijians; it is still very much a part of the political culture of Fiji. Both groups continue to vote for those parties that have the highest levels of communal appeal. Party policies and political manifestos rarely receive close scrutiny from the electorate. As a result, ethnic block voting, with its emphasis on ethnic allegiances, is commonplace, and religious persuasion acquires political salience. This chapter aims to assess the extent to which Indo-Fijian religious organizations continue to influence the electoral process, and the way in which this is achieved. In order to understand the culture of Indo-Fijian politics, we need to begin by understanding the origins of intra-communal divisions, which continue to shape political realities. 


\section{The myth of the Indian 'community'}

To the gaze of the outside world, Fiji begins with the Fijians and ends with the Indians: two neatly packaged identities that need little explanation and can be interpreted without difficulty. These two truncated forms of grand traditions are regarded as unproblematic and immediately accessible. The international media chose to adopt this interpretation in order to portray the coups of 1987 and 2000. However, such a view fails to take account of the degree of fragmentation that exists within both communities. In the case of the Fijians, challenges to the idea of group homogeneity are based upon regional power struggles, which have led to a fragile political unity during elections. ${ }^{5}$ This is highlighted by the elections of April 1977, 1987 and 1999, when divisions within the community led to defeat for each of the parties presumed to have majority ethnic Fijian support. In order to avoid a repeat of this during the 2006 election, and in part also because of the large number of parties (20) contesting in Fijian communal seats, calls were made for Fijian unity.

A number of divisions exist within the Indian community; these developed historically as a result of the indenture process and, later, during the postindenture period. They generated distinct regional and linguistic identities, which would later crystallize around new religious organizations and lead to the formalization of deep hostilities. Beneath the umbrella term 'Indian' are a number of religious groups - Hindus, Muslims and Sikhs - each claiming a distinct cultural heritage and identity on which they continue to draw. Further sources of differentiation resulted from the various regions from which they originally came - particularly the divisions between northern and southern Indians, which in turn led to linguistic divisions. ${ }^{6}$ The arrival of free Indians - mainly Punjabis and Gujaratis who paid their own fares to Fiji in order to provide services for the indentured labourers - led to strained relationships between the two groups, as the later-arriving free Indians prospered to a greater degree than did the former indentured labourers. ${ }^{7}$

During the indenture period, these differences were irrelevant, due to the shared experience of living through narak, or hell, as the labourers referred to it. This provided them with a shared identity based upon the suffering they endured $^{8}$, and was further strengthened by the concept of the jahazi bhai ('ship brothers'). Ship brothers were the fictive kin who had travelled together 
from India and worked together on the plantations. Their relationships were based upon common experience, and cut across religious, regional and caste differences, with groups co-existing and sharing in one another's culture and religious functions. Such was the extent of interaction between the two groups that an early mosque was built at Nausori with funds largely contributed by Hindus prior to $1920 .{ }^{9}$ However, such generosity was short-lived; during the post-indenture period of the 1920s and 1930s, differences became apparent when various religious groups began organized programs of building schools, temples and mosques. ${ }^{10}$ Indians formed groups to advance these objectives - often with the guidance of missionaries brought from India. It was these missionaries from outside the colony who highlighted the differences between groups and led to the formation of oppositional identities.

Romila Tharpar convincingly argues that Hinduism is an 'invented modern tradition' from which an ancient identity was constructed during the 19th century. By drawing together a number of local traditions ${ }^{11}$, political support was mobilized for Indian independence. ${ }^{12}$ As a modern construct, the term Hinduism remains a contested category. In the absence of a clear definition of what Hinduism was, two major streams emerged - Sanatan Dharm ${ }^{13}$ (the Eternal Tradition) and Arya Samaj, both of which vied for authenticity in India and, subsequently, Fiji. ${ }^{14}$ The Sanatanis are regarded as orthodox; they emphasize the importance of the Epic tradition of the Mahabharata and Ramcaritmanas. Integral to the faith are deity worship and ritual performances. Its devotees regard it as the most accessible form of Hinduism due to its emphasis on bhakti (devotional) forms of worship. In Fiji, the Shree Sanatan Dharm Pratinidhi Sabha (SDS) has the largest following of any of the Indian religious organizations. It was established in 1928 to improve literacy and education among Indians, but also to provide a countervailing voice to the reformist Arya Pratinidhi Sabha (APS/Fiji). ${ }^{15}$

The Aryas dominated the political scene in Fiji in the period immediately after indenture, establishing a central body in $1917 .{ }^{16}$ In contrast to the Sanatanis, the Aryas adhere only to the Vedic tradition. They reject the Epics and what they regard as the superfluous rituals attached to them. Bitter debates erupted between the two groups during the late 1920s and early 1930s. ${ }^{17}$ These controversies were largely instigated by several preachers, and 
played out variously in public debates and the media, which focused on child marriage, widow remarriage, and the sexual conduct of prophets and gods. Several controversial published works critical (often obscenely so) of religious leaders from the Sanatan, Arya and Muslim faiths were imported. ${ }^{18}$ The Aryas were scornful of the Sanatan corpus of the Epic tradition, especially the Ramcaritmanas, which led to heated debates between the two groups. These debates tore the Indian community apart at the time, and left it weakened when negotiating with the colonial government and sugar companies. Whilst the divisions are still evident today, they are not as pronounced as they were in the 1930s and 1940s, and tend to be focused on fundamental differences in religious practice. Politically, this has led to divisions between the groups during the post-independence era. Most notably, the APS/Fiji originally supported Ratu Mara's Alliance Party, but subsequently shifted support to the FLP; most of its members, it is believed, then shifted to the SDL party in 2006. By contrast, the leadership of the SDS has consistently supported the National Federation Party (NFP).

Further divisions within the Hindu community arose between those originating from northern India and those from the south (the latter arriving in Fiji as indentured labourers later than the former). Those of south Indian origin, despite being Sanatan Hindus, bore the brunt of what may be termed 'black-racism' as a result of them generally having a darker skin tone than north Indians. Culturally and historically, they were perceived as different from the other migrant communities. ${ }^{19}$ Forming only a quarter of the Indian population, they were victimized as a minority group. In some instances, Indian community schools in western Viti Levu refused to admit south Indian children. This demonstrated a belief widely held by south Indian families that, as a socially isolated and economically marginalized group, they counted for little in the social and political agenda of the Fiji Indian leadership. ${ }^{20}$

Reaction to exclusion and disadvantage led to the formation of the TISI Sangam in 1926. Through the preservation and promotion of south Indian culture, that organization sought to protect people of south Indian origin from prejudice, while at the same time providing an educational base for the south Indian community. Despite being closely identified with the Sanatan religious tradition, the TISI Sangam considers itself a cultural organization, 
open to members of various religious backgrounds as long as they are able to trace their ancestral roots to south India. However, the idea of a unified south Indian group was short-lived as divisions began to appear within the Sangam. Telugu-speaking Indians originating from Andhra Pradesh felt that their interests were not being represented. A prominent leader from Andhra Pradesh, Alipaty Tataiya, accused the executive members of the TISI Sangam of deliberately recruiting unqualified people to executive posts within the TISI Sangam in order to ensure that they would receive no opposition in the promotion of the Tamil community and culture. ${ }^{21}$ Future leader of the NFP A.D. Patel was at the time legal advisor to the TISI Sangam executive, and a target for Telugu criticism. ${ }^{22}$ This led Tataiya, who was one of the founders of the TISI Sangam, to found a separate organization, the Andhra Sangam (AS), in 1941, to protect the interests of the Telegu-speaking community. This mirrored events in India, where active agitation would eventually lead to the creation of the state of Andhra Pradesh in 1953. As a result, the Andhra Sangam sustained a long-run hostility towards A.D. Patel and the NFP. While these hostilities are no longer as pronounced, they still continue to influence the pattern of support for political parties. In recent elections, the leadership of the TISI Sangam has continued to support the NFP, while the leadership of the Andhra Sangam has supported the FLP. ${ }^{23}$

Another minority group in Fiji, the Muslims, began to assert their communal identity during the 1920s, partly as a result of increased religious and political tensions in India. The Fiji Muslim League (FML) was formed in 1926 , and was to serve as a central coordinating body that would try to realize the ambitions of Muslims to hold office. ${ }^{24}$ It also made possible a unified Muslim voice against the activities of the Arya Samaj in Fiji - and especially against its preacher, Sri Krishna. Sri Krishna preached that the Muslims and Indian Christians were against progress, a claim that generated considerable anxiety on the part of the Muslim community. ${ }^{25}$ Since the 1920s, the FML has resisted Muslim incorporation into the Indian communal rolls, agitating for separate representation based upon distinct Muslim religious and cultural identity and history. The rift between the Aryas and FML was reinforced by the experience of Hindus and Muslims during the partition of the Indian subcontinent during independence. Following Fiji's independence in 1970, 
the call for separate Muslim representation found considerable support from sections of the indigenous Fijian élite, who saw it as a means of decentralizing the Indian community's numerical strength. In the aftermath of the 1987 coup, the leadership of the FML gave its support to the Great Council of Chiefs' proposal for Fijian dominance in Parliament, in the hope that it would lead to them receiving separate political representation. ${ }^{26}$ Lal suggests that this effectively provided support for the Nationalist Taukei Movement. ${ }^{27}$ A section of the Muslim community was instrumental in helping to establish the Alliance Party $^{28}$ and maintained strong relationships with it - and later the SDL party - after independence; however, they are pragmatic when it comes to securing their goal of separate representation, and backed the FLP in 1999.

A significant cleavage, which continues to influence the culture of politics in Fiji, is the division between those who arrived as free Indians (Gujaratis and Punjabis) and those descended from indentured labourers. The free Indians were more successful in maintaining a distinct identity in the post-indenture period, partly because their ties to their homeland and their freedom to return whenever they chose meant that family ties were maintained - with twoway trade, in remittances from Fiji, and in merchandise from India, being established. Cultural and linguistic traditions were also maintained and renewed through visits 'home' for marriage etc. Most Gujaratis chose not to wed Fiji Indians, but to return to India to marry within their caste. Caste remained important for Gujaratis, as most immigrants from the same caste were related, which in business meant that they joined together to fight against non-Gujarati competition. This sense of group loyalty was an aid to their business success, but also led to resentment from other, less successful, groups. Several Gujarati families continue to enjoy considerable business success: Vinod Patel, Tappoo and R.C Manubhai being prime examples. ${ }^{29} \mathrm{~A}$ further source of differentiation is that Gujaratis, as Hindus, have tended to align themselves with the APS/Fiji; this places them in a minority compared with the majority Sanatani community.

Gujarati merchants were instrumental in establishing and funding the NFP in $1960 .{ }^{30}$ It is claimed that they were also able to control the political loyalties of their indebted farmer customers. ${ }^{31}$ Nevertheless, consciousness of potential resentment due to business success and the threat that this might jeopardize the intended aim of the party to represent cane growers, led those 
early Gujarati leaders to quickly relinquish control. Divisions within the NFP in 1977 (outlined in further detail below) led many in the Gujarati community to move to the Alliance for the 1982 election, a liaison encouraged by close links established and maintained by way of joint ventures with Fijian élites, and by the Alliance Party's promise of 'business as usual'. ${ }^{32}$ The promise of a stable economy has subsequently proved to be an important influence over Gujarati political loyalties, and in 2006 it is widely believed that they placed significant support behind the SDL.

Divisions within the Indian community continue to persist, although in new shapes and forms. It has been suggested that a group of Indian businessmen funded the 2000 coup against Chaudhry's government owing to fears that the FLP's pledge to root out corruption would damage their business interests. Mahendra Chaudhry made similar claims on the FLP website, stating that several Indian businessmen had 'actively assisted the rebel elements in Labasa with food and cash $^{33}$, in the hope of thereby dispelling the myth that the coup was racially motivated. Despite Chaudhry's claims, no Indian businessmen have been charged in relation to the 2000 coup.

\section{Voter alignment in the past}

Despite occasionally severe divisions, the Indian community has, at times, aligned itself with political parties during elections. An early example of religious divisions influencing voting patterns occurred during the 1929 election for the Legislative Council. This was the first time that Indians were permitted to elect members, albeit on a communal franchise. In the eastern constituency, two candidates stood, one, Khalid Sahim, was a Muslim, the other, James Maharaj, was a former Arya Samaji who had converted to Christianity. Out of the 83 valid voting papers, 63 had voted for Maharaj, and 20 for Sahim. It was claimed by the FML that, having become tools of the Arya Samaj, the Hindus had voted en bloc by 'herd instinct', as the other two winning candidates were also Arya Samajis. ${ }^{34}$ Later, the divisions between the Arya Samaj and the Muslim community would heal, enabling them to form alliances. During the 1951 Legislative Council election, the FML supported a political leader strongly linked to the Arya Samaj. A request was made of the Muslims in the rural constituency of Namboulima to vote for this candidate, which they duly 
did. ${ }^{35}$ This alliance is still in evidence today. During the 2006 election it was widely believed that the leadership of the FML and APS/Fiji supported the SDL, the reasons for which are examined below.

The events surrounding the April 1977 election provide a telling example of the role played by religion in politics. The outcome was an unexpected, but narrow, victory for the NFP and defeat for Ratu Mara's Alliance Party, by 26 seats to 24 . Yet, in the wake of the poll, the Governor General exercised his power of discretion to return the Alliance Party to power under the leadership of Ratu Mara, rather than handing the reins to the leader of the NFP, Siddiq Koya. His reasoning for this was that the country had failed to provide a clear mandate and that Mara was the person best able to command the support of the majority of members of parliament. Internal divisions within the NFP before the election led to speculation that it was members of Koya's own party that had informed the Governor General that they would be unwilling to work with Koya. It was suggested by Koya some years later that his Hindu colleagues withheld their support for him, as they did not want a Muslim prime minister. ${ }^{36}$ Mara's government was later toppled by an NFP-led vote of no confidence, which led to fresh elections being held in September 1977.

In that election, both sides exploited religious divisions. The NFP was divided into two factions - known as the 'flowers' and the 'doves'. The flowers, led by K.C. Ramrakha and Irene Jai Narayan, were widely regarded as a Hindu party, whilst Koya led the doves, commonly believed to be a Muslim party. ${ }^{37}$ The campaign was characterized by the manipulation of religious symbols for political gain. Hindus were urged to vote for the flower, which is commonly used in practices of Hindu religious worship, whilst advertisements for public meetings organized by Irene Jai Narayan of the flower faction featured a caricature of her with her hands clasped together as in prayer; flanking the corners of the advertisement the clasped hands were reproduced and enlarged. ${ }^{38}$ The language used during the election was also designed to manipulate religious sentiment - Koya was described by Ramrakha as a 'high priest who was trying to set up a rival temple', ${ }^{39}$ an allusion to the NFP as a strongly religious and sacred body. The divided NFP subsequently lost the election, with the Alliance Party being returned to office with a stronger majority. Koya claimed that the 
loss was because the leaders of the flower faction had 'sown the seeds of discord in the Indian community, setting Hindus against Muslims'. ${ }^{40}$

\section{Hafizud Dean Khan and the FML}

Claims that religious organizations continue to influence the political process are strongly denied by both parties and religious organizations alike. After the death of former SDL Minister for Information, Ahmed Ali, in 2005, the SDL party appointed the FML president, Hafizud Dean Khan, as his successor to the Senate. He maintained a high-profile relationship with Qarase, which led many commentators to predict that the 2006 election would see significant increases in the Muslim vote for the SDL at the expense of the FLP. When the election candidates were announced, it was revealed that the SDL would be fielding Muslim candidates in nine out of the 21 Indian communal constituencies, and in four out of the seven open seats in which it had placed Indian candidates. This was disproportionate to the size of the Muslim community, and indicates a strategic attempt to swing votes away from the FLP. Whilst the FML did not make any public statements in support of the SDL, nor ask their members to vote for the party, it was believed that the close relationship that developed between Hafizud Dean Khan and Qarase indicated some measure of political support. ${ }^{41}$

Traditionally, some leaders of the FML have pragmatically supported those parties that went on to form the government. Because of their pragmatism, they maintained a strong relationship with the Alliance party. In previous years, all parties tried to court the support of the Muslim community. ${ }^{42}$ However, in the 2006 election, Muslim candidates did not win any of the Indian communal seats. While the leadership of religious groups, like the FML, may maintain high profile relationships with political leaders, it does not follow that the rank and file membership will follow. During the 2001 election, the leaders of several religious organizations contested seats. D.S. Naidu, president of the TISI Sangam, stood for the NFP in his home constituency - Nadi Urban Indian Communal - in which is located the iconic Sri Subramaniyam temple. Yet, the NFP vote fell by 0.5 per cent in the constituency compared with the 1999 result. This pattern was repeated in the Nadi Rural Indian Communal constituency, in which Surendra Kumar, president of the SDS, stood in 2006. 
Again, he stood for the NFP in his home constituency, but failed to win the seat, delivering a 4.5 per cent drop in the NFP vote compared with the previous election. The secretary of the AS, Immanuel Manu, ${ }^{43}$ also stood for the NFP in Nadroga in 2006, but secured only 5.2 per cent of the vote at the first count and lost to the FLP candidate. ${ }^{44}$

Similarly, when religious leaders stand down, it seems to have little impact on electoral outcomes. APS/Fiji leader Kamlesh Arya vacated his Laucala Indian Communal seat just before the 2006 election. He had won the seat in 2001, with a 9.5 per cent increase on the previous election. In 2006, a new candidate contested the seat for the FLP, winning by a margin similar to that of his predecessor. This suggests that the votes cast in 2001 were for the FLP, rather than for Kamlesh Arya, as president of the APS/Fiji.

\section{The FLP and the Chaudhry effect}

It seems likely that rank and file members of most Hindu and Muslim religious organizations voted for the FLP in the Indian Communal constituencies in 2006. Prior to the election, Chaudhry suffered considerable setbacks when several high-profile MPs announced that they would not be re-contesting their seats. Some suggested that this was the end of his career. Yet, Chaudhry remained a strong and popular leader with the Indian electorate, with support cutting across religious and cultural boundaries. Results in the Indian Communal constituencies at the 2006 election show that, out of a total of 165,398 valid votes, the FLP won 134,022 (81\%), whilst the NFP polled 23,263 (14\%) and the National Alliance and SDL parties had a combined Indian Communal vote of 7,000 (4.2\%). ${ }^{45}$ The FLP's vote was also reasonably steady across the country, suggesting that variation in religious affiliation had little impact. ${ }^{46}$

Divisions within religious organizations also called into question the political credibility of the organizations. Both the AS and TISI Sangam, in unrelated incidents, had suffered from internal problems, which led to a loss of confidence in their leaders and attempts to replace them. With both of the south Indian groups in disarray, it seems unlikely that they would have appeared credible advocates for one or other of the major parties in the eyes of their members during the election. The electoral influence of the SDS is also open to question. With a claimed membership in excess of 200,000 people, academic Ganesh 
Chand suggests that the SDS is too big an organization to be able to influence voting preferences at grassroots level. ${ }^{47}$

The real source of influence rests with the individual Ramayan mandalis (local congregations), located throughout Fiji. The purpose of these organizations is to encourage the reading of religious texts in a group setting; however, due to their relatively small size, these localized units are also better equipped to encourage informal political debate. While, officially, candidates are not permitted to use the mandali as a political platform, many candidates and people close to them are members of them and able to informally circulate their political message. Hock points out that the SDS as a national organization grew out of the mandali system. ${ }^{48}$ However, a number of sources suggest that few of the mandalis have regular formal contact with the SDS executive, and so are free from any executive influence.

Candidates have also used religious events for political gain. The 2006 election fell during three religious festivals - Ram Naumi (Hindu), Easter (Christian) and The Prophet Mohammed's Birthday (Muslim). Each was used as a platform by election candidates to address potential voters. Lek Ram Vayeshnoi, who stood for the FLP in the Nadroga Indian Communal constituency, attended a religious event at a private house at which he gave a speech on good governance. For Vayeshnoi, 'religious functions are one of the few places where young and old are together - as such this is why religion is used as a weapon to get votes'. ${ }^{49}$

A number of factors contributed to Mahendra Chaudhry's success in attracting Indian votes in 2006, including compulsory voting and increased voter awareness of issues arising from comprehensive media coverage. ${ }^{50}$ Disputes between the army and the governing SDL also appeared to make another coup a less likely accompaniment to a 1999-style FLP victory. What of the role of religious convictions? Chaudhry's close ties to India and his well-documented religious beliefs mean that he is seen as a leader reflecting Indian values, as well as one with a strong record of defending Indian interests. As mentioned above, Chaudhry is often venerated with quasi-religious respect, with his photo adorning the walls alongside a pantheon of gods, and his strident condemnation of injustice echoing lingering popular bitterness about the experience of indenture and the coups of 1987 and 2000. The comparisons 
with Rama's banishment continues the popular theme of suffering within the Indian community, and places Chauhdry as the inheritor of a tradition that extends from the indentured labourers to the present.

\section{7: A time for change}

The changing relationship between Indian religious organizations and the political scene can be seen by the response to the coups of 1987 and 2000 . Writing three years after the 1987 coup, John Garrett talked of the silence of the Indian community, which had previously been vocal and assertive through the NFP. He found instead a 'silent citizenship' alternating with occasional non-violent protests. These protests were mobilized through trade unions rather than religious groups, and it was the unions which increasingly voiced Indian political concerns. ${ }^{51}$ There were no explicit statements from religious groups condemning the coups, partly due to the internal divisions within both the Hindu and Muslim communities.

There were other, more problematic, reasons for Indian silence. The everpresent threat of targeted violence against those speaking out is highlighted by the case of Chandrika Prasad, who filed a lawsuit in which he claimed that the interim government installed in 2000 was illegal. He won his case, bringing into question the legitimacy of the interim government. On the day his victory was announced, another farmer with the same name was seriously assaulted in what is believed to have been a case of mistaken identity. In the wake of the coups, Fiji Indians '... had few public forums within the country where they felt safe to voice their grievances' ${ }^{52}$ Indian places of worship were attacked, adding to the sense of a community under siege. ${ }^{53}$ During the 2006 election campaign, a temple in Waila Nausori was broken into, which led Chaudhry to propose an intelligence network for the police to curb attacks on places of worship. ${ }^{54}$

The falling Indian population after 1987, owing to significant numbers leaving for overseas, further heightened the sense of insecurity. In 1986, the Indians had been the majority population, with 347,445 people (48.6\%) compared with the Fijian population of 330,441 (46.2\%). ${ }^{55}$ In the months after the 1987 coup, large numbers of well-educated professionals fled the country, settling in Australia, New Zealand and America; this was repeated after the 2000 coup. ${ }^{56}$ Perhaps 80,000 or 90,000 Indians have left the country since 
1987, around 20-25 per cent of the 1987 population of Indians. Numbers have continued to fall, and the current population is 316,093 compared with a Fijian population of $463,432 .{ }^{57}$

In the aftermath of the 1987 coup and subsequent political upheavals, Indian religious organizations began to distance themselves from the political process. The desire to separate religion and politics is understandable given Rabuka's post-coup rhetoric, in which he claimed, for example, his role as coup leader to be a mission ordained by God, and referred repeatedly to both Hindus and Muslims as heathens. ${ }^{58}$ Rabuka also famously declared that he wanted to turn Fiji into a Christian state:

Those that do not choose to become Christians can continue to live here but they will probably find it a difficult place to live in, for we may not have Hindu religious occasions celebrated as such, and their holy days may not be holy days from now on. ${ }^{59}$

These sentiments were echoed in the Assembly of Christian Churches in Fijis 2006 election advertisement, which called for Fiji to be ruled by the laws of God (see Newland, this volume). Against this backdrop, Hindu and Muslim religious organizations have chosen to remain quiet, in order to avoid becoming a visible target for attack. They have moved their attentions to forcing the education agenda as a way of maintaining their influence over the political process. It is an area in which they have a long-standing interest.

\section{Education: for the future or for security?}

Education had always been a priority for Fiji's Indian community, particularly after the end of indenture. After 1987, it took on an added urgency in that it offered a degree of security. An Indian student at the University of the South Pacific commented to me, '...they can take away my land and my home, but they can't take away my degree... with my degree I can escape and start a new life if things become difficult' ${ }^{60}$ This sentiment is widely held by Indian families from across the various communities.

In a country in which few Indians own land ${ }^{61}$, education is regarded as the most important thing the Indian community can provide for their children: it offers security through financial independence. With this in mind, most Indian religious organizations have established a range of educational institution ${ }^{62}$, 
with most of them either having expanded into the tertiary education market, or having plans to do so in future. While these schools are owned and run by the various religious groups, they rely heavily on government support and funding to provide teachers' pay, grants and loans for building repairs, scholarships, academic accreditation and curriculum planning. It is because they provide funding and are involved in the day-to-day running of schools, that most religious groups wish themselves to be seen as politically neutral, as to align oneself with a particular political party could jeopardise future sources of funding.

However, education is not the exclusive concern of the Indian community. A Tebbutt poll in The Fiji Times indicated that 41 per cent of ethnic Fijians identified it as their most significant concern during the 2006 election. ${ }^{63}$ As education has broad appeal, it is a safe issue around which religious organizations can influence the political agenda. During the election, the president of the SDS, Surendra Kumar, requested the newly elected government to allocate approximately $\mathrm{F} \$ 50,000$ to registered religious groups, in order to alleviate the financial hardships that forced children to leave school:

I urge the government to help poor children in all levels of education... religious groups are the best means by which they can support poor children...the government and religious groups should work in partnership to provide scholarships to children in primary and secondary schools. We can curb social problems by making families feel they are wanted. ${ }^{64}$

In this way the political agenda shifts to social policy, with poverty alleviation and crime and disorder entering the debate. The continuing struggle to secure funding lies at the heart of the political debate around education, with parties conscious that this is a significant vote-winning issue. Mindful of this, the then Minister for Multi-Ethnic Affairs, George Shiu Raj, stated that his ministry would provide more than 8,000 scholarships over the next parliamentary session if the SDL were re-elected, this being an increase of 2,400 on the previous parliamentary session, when 5,600 scholarships were distributed. ${ }^{65}$

Further promises were made to help religious groups establish nursing schools for students unable to secure a place at the Fiji School of Nursing. With an eye to wider policy issues, Shiu Raj stated that: 
The setting up of nursing schools would ease the lives of many families when their children graduated and started working... If 1,000 nurses graduated each year from the schools, the problem of poverty would be solved. The graduates could work locally or migrate to countries that needed their skills...foreign earnings would increase because they would send money back home to their families. ${ }^{66}$

The government saw the expansion into tertiary education and the sending of nurses overseas as a way of increasing national wealth and reducing unemployment.

The official reason for the founding of the University of Fiji ${ }^{67}$ was that it would have a Fiji focus, something that the University of the South Pacific was unable to do as it serviced the educational needs of 12 Pacific nations. The decision was prompted by the need to provide a home for Indian students who perceive themselves to have been marginalized under the affirmative action schemes of successive governments since 1987. During his June 2005 speech to open the AD Patel Centenary Carnival in Ba, Professor Rajesh Chandra, the Vice-Chancellor of the University of Fiji stated:

In a very real sense, the Indian community had been searching for some time for a way to expand the provision of higher education in Fiji, and to avoid its dependence on the government-controlled University of the South Pacific. Despite having access to the University and the obvious benefits of the USP to Fiji, people in Fiji had been feeling that their access was being limited by quotas or threats of quotas, and that people in the Western Division and those in the Northern Division did not have good access to higher education in the way that the residents of Suva and surrounding areas had... [T]he University is fulfilling the dreams that AD Patel, Pandit Vishnu Deo, and other leaders had, and the dreams that the Indo-Fijian community had to ensure that it had good access to high quality higher education. ${ }^{6}$

The founding of the University of Fiji may be seen as a politically motivated decision, but its establishment was dogged by problems. The Minister for Education, Ro Teimumu Kepa, tried to prevent the name 'University of Fiji' being used, whilst it was unclear as to whether or not government funding and accreditation would be forthcoming. At the start of the 2006 election campaign, the two people most closely identified with the establishment of the university - Ganesh Chand and Kamlesh Arya, both FLP MPs - announced that they would not be re-contesting their seats at the forthcoming election. A week prior to this announcement, both Arya and Chand had been with SDL 
leader and Prime Minister Qarase at a high profile dedication function at the University of Fiji. The FLP leaders were absent from the event, with no reason given for their absence. Arya claims that the FLP had been invited, and that he hand-delivered an invitation to Chaudhry. In addition to this he had 'personally cajoled several of them [FLP members] to come but they were not there. ${ }^{69}$ In the weeks prior to the dedication ceremony, Arya had publicly criticized Chaudhry. ${ }^{70}$ At the same time, Qarase strengthened the relationship between the SDL and Arya Samaj by saying at the dedication, as quoted in The Fiji Times: 'The SDL coalition and the motivating spirits behind the new university had a shared belief in the high importance of education' ${ }^{71}$ In making such a statement, Qarase was able to plant in the public mind the idea that the two organizations had a shared vision for Fiji, and touched on an issue of importance to Indian voters - that of education. At the same time, the motivating spirits, Arya and Chand, were two former FLP members who had left the party due to disagreements with its leadership.

The public perception of these events was well illustrated by a letter titled 'Bad Leader' printed in The Fiji Times during the election campaign. In it, the author accused the SDL of orchestrating Mr Arya's public condemnation, and departure from the FLP, and said that Mr Arya willingly went along with it for personal gain. It was alleged that it was done in order to secure the victory of the SDL party, which, in turn, would provide government grants for the University of Fiji. ${ }^{72}$ Whether this is true or not, it represents a suspicion that was around at the time. It is unclear whether or not this was deliberate political positioning by the Prime Minister in order to win votes; however, as with Hafizud Dean Khan and the FML, this did not translate to rank and file votes migrating to the SDL Party. ${ }^{73}$

\section{Conclusion}

The way in which religious organizations influence the political process has altered over time. In the post-indenture period, divisions between religious groups resurfaced, and led to the establishment of a number of religious and quasi-religious groups dedicated to the protection and promotion of education and culture. Through the post-war years, the leadership of these groups was able to influence voting patterns and provide religious blocks of support to a 
particular candidate or party. After 1987, there was a movement away from this style of direct support for political parties. Increased political sophistication in the electorate, with information drawn from a number of sources, means that religious organizations are no longer such a powerful source of opinion during election campaigns. While religious leaders may align themselves with particular parties, it does not follow that rank and file members will follow their lead - as the cases of D.S. Naidu and the TISI Sangam, Surendra Kumar and the SDS, and Immanuel Manu and the AS demonstrate. Whilst the leaders of religious bodies may have political ambitions, their members do not necessarily share these. As a result, organizations that were once vocal backers of political parties are now more circumspect when making political statements, tending to focus only on those issues that the public expects them to speak on - such as education policy, temple desecration and the Promotion of Reconciliation, Tolerance and Unity Bill. ${ }^{74}$ They have, however, found that, through their focus on education and its expansion, wider issues of social policy can be debated, and the political agenda shaped. The 2006 election resulted in a multiparty cabinet - with individuals from various ideological persuasions coming together for the national benefit. Similarly, while divisions between the different Indian religious groups persist, and are essential in sustaining Indian identity, the movement towards the expansion of higher education can be seen as these groups working together for a common cause. However, the question remains whether this is for the national benefit or for the betterment of a specific community.

\section{Notes}

1 This paper deals with the following organizations:The Fiji Muslim League (FML), The Arya Pratinidhi Sabha of Fiji (APS/Fiji), The Shree Sanatan Dharam Pratinidhi Sabha (SDS), The Dakshina Andhra Sangam (AS) and Then India Sanmarga Ikya (TISI) Sangam. Thanks to Jon Fraenkel, Linda Newland, Robert Norton and Biman Prasad for comments on an earlier draft of this paper; however, any errors or omissions remain the responsibility of the author.

2 Fiji Bureau of Statistics. 1996. <http:/www.spc.int/prism/country/fj/stats/cens\&surveys/ Popu_census.htm - accessed 2/6/2006. These statistics, whilst the most up-to-date official statistics on religion issued by the Fiji Bureau of Statistics (1996), are subject to query. Newland highlights that the figures fail to reflect the rise of new religious groups, such as the International Society of Krishna Consciousness (ISKCON), nor do they accurately reflect the true membership of organizations. As an example, the official statistics for the Sai Baba movement are recorded as 60 members, whereas the organization claims a membership of 2,000 . Similarly the statistics do not take account of those organizations that are not deemed 
to be religious organizations but rather ethical bodies. Newland, L. 2006. 'Fiji' in Ernst, Manfred (ed.) 2006. Globalization and the Re-shaping of Christianity in the Pacific Islands. Pacific Theological College, Suva.

3 See Newland, this volume.

4 SDL Manifesto 2006:3.

5 Durutalo, A. 2000. 'Elections and the Dilemma of Indigenous Fijian Political Unity' in Lal, B.V. (ed.) 2000. Fiji Before the Storm: Elections and the Politics of Development, Asia Pacific Press, The Australian National University, Canberrra. pp.73-93; Norton, R. 1990. Race and Politics in Fiji (2nd edition), University of Queensland Press, Queensland. pp.49-50.

6 Lal, B.V. 1983. 'Girmitiyas: The Origins of the Fiji Indians', Journal of Pacific History, Canberra. pp.43-67.

7 Lal, B.V. 1992. Broken Waves: A History of the Fiji Islands in the Twentieth Century. Pacific Islands Monograph Series. No 11. University of Hawaii Press, Honolulu. pp.77.

8 For further details of this period see Naidu, V. 2004. The Violence of Indenture in Fiji. Fiji Institute of Applied Studies, Lautoka; and Prasad, R. 2004. Tears in Paradise, Glade Publishers, Auckland.

9 Gillion, K.L. 1977. The Fiji Indians: Challenge to European Dominance 1920-1946. Australian National University Press, Canberra. pp. 150.

10 Ali, A. 1977. 'The emergence of Muslim separatism in Fiji'. Plural Societies, 8(1):57-69; Norton, R. 1990. Race and Politics in Fiji, pp.50.

11 This idea is given further credibility by others. See, for example, Singer, M. 1972. When a Great Tradition Modernizes; An Anthropological Approach to Indian Civilization, Pall Mall, London, and M.N. Srinivas. 1976. The Remembered Village, Oxford University Press, Delhi.

12 Tharpar, R. 1989. 'Imagined Religious Communities? Ancient History and the Modern Search for a Hindu identity', Modern Asian Studies, 23(2):228.

13 A number of groups subscribe to the Sanatan Dharm philosophy; however, further divisions have led to the formation of additional groups in Fiji. These include the SDS, the AS and TISI Sangam.

14 Kelly, J. 1991. A Politics of Virtue: Hinduism, Sexuality and Counter-Colonial Discourse in Fiji, University of Chicago Press, Chicago and London, pp.126-39, 206-18.

15 A comprehensive overview of the SDS and APS/Fiji can be found in Hock, K. 'Non Christian Religions in Fiji' in Ernst (ed.) 2006, Globalization, pp.390-439.

16 Kelly, J. 1991. A Politics of Virtue, pp.128.

17 Detailed treatment of these events is provided by Kelly. 991. A Politics of Virtue; and Gillion. 1977. The Fiji Indians, pp.108-11.

18 Kelly, J. 1991. A Politics of Virtue, p.208.

19 See Mayer, A. 1961. Peasants in the Pacific. Routledge and Kegan Paul; London, pp.144149.

20 Lal, B.V. 1997. 'A vision for change: A D Patel and the politics of Fiji', History of Development Studies 6. National Centre for Development Studies, The Australian National University, Canberra, p. $51 .{ }^{21}$ Krishna, A. 1973. 'History of the Andhra Sangam in Fiji' (unpublished SE300 thesis) University of the South Pacific, Suva, p.31; Fiji Girmit Council. 2004. Girmits Greatest Gift. Commemorative publication to celebrate the 125th Anniversary of the first arrival of Indians in Fiji. Unknown publisher. 
When the TISI Sangam was registered as a company in 1937, Patel became its general manager (Gillion 1977:111).

23 Interview with Vinod Naidu, National President of the Dakshina Andhra Sangam, 13 March 2006.

24 Ali, A. 1977. 'The Emergence of Muslim Separatism in Fiji', p. 60.

25 Ali, A. 1977. 'The Emergence of Muslim Separatism in Fiji', p. 61.

26 The Fiji Times, 10 August 1987, p.1.

27 Lal, B.V. 1992. Broken Waves, p.286.

28 Norton, R. 1990. Race and Politics in Fiji, p.86.

29 Gillion, K L. 1962. Fijis Indian Migrants: A History to the End of Indenture in 1920, Oxford University Press, Melbourne and New York, p.135.

30 The TISI Sangam and Ramkrishna Mission also had a significant role in its foundation.

31 Norton, R. 1990. Race and Politics in Fiji, p. 78.

32 Lal, B.V. 1986. Politics in Fiji. Allen and Unwin, Sydney.

33 'Labour slams Labasa businessmen' http://www.flp.org.fj/N030123.htm - accessed 10 July 2006

34 Ali, A. 1977. 'The Emergence of Muslim Separatism in Fiji', p.62.

35 Mayer, A. 1961. Peasants in the Pacific, pp.148-49.

36 Lal, B.V. 1992. Broken Waves, p.240.

37 Despite the commonly held belief that the Doves were a Muslim party - a view perpetuated by the 'Flowers', Koya also had the support from significant sections of the South Indian community (Biman Prasad - Pers. Comm 8/8/2006).

38 The Fiji Times 6 August 1977, p.3

39 The Fiji Times, 12 August 1977, p.1.

40 The Fiji Times, 30 September 1977, p.4.

41 Interview with the 2006 SDL campaign team (Sivoki Matenamia - Manager, Political Awareness; Angve Davetawalu - Operations Manager, Nausori Cluster; Mosese Vosavogo Manager IT Services and Communications; and Viliame Sotia - Manager Research Media) 9/6/2006.

42 At approximately 8 per cent of the population they are regarded as a significant support base.

43 That Manu stood for the NFP while the leadership of the AS gave their support to the FLP demonstrates that religious organizations are no longer dogmatic in their support of political parties.

44 Comprehensive statistics for the 2001 elections are available at http://psephos.adam-carr. net/countries/f/fiji20013.txt

45 This contrasts with the elections of 1999 when, out of 165,886 votes cast, 108,743 went to the FLP and 53,071 to the NFP. In 2001, 145,428 votes were cast, of which 108,459 went to the FLP and 32,142 to the NFP. Progressively, the FLP have been the beneficiaries of approximately 30,000 NFP votes, which may have come either from members of the TISI Sangam, or from the SDS. See http://psephos.adam-carr.net/countries/f/fiji20013.txt

46 A member of the public at the first Fiji Institute of Applied Studies (FIAS) public debate on the 2006 election (Waterfront Hotel, Lautoka, 15 May 2006) commented that most of the candidates on the voting slips were unknown and that the electorate voted for Chaudhry rather than the individual candidates. 
47 In rural areas, power and influence operate at a grassroots level. Ganesh Chand suggests that the 'gang sirdar' - the head of the cane-cutting gang in cane-farming areas - is able to influence voting outcomes. His role is to decide the order in which cane cutting is to take place. Cane, which is cut later in the season, is drier, earning less for the farmer. If the gang sirdar were to support a particular candidate, it is likely a majority of farmers would go along with his decision in order to win his favour (Chand, interviewed 15/06/2006). Hock. K. 2006. 'Non Christian Religions in Fiji', p.393.

Unpublished election report by Sunayna Nandni, student journalist at the University of the South Pacific, see also her report 'Campaigning a Family Affair for Vayeshnoi' http://www. usp.ac.fj/journ/wansolnews/2006/elections2006/april/wansol1205061.html. Accessed 10 June 2006.

50 A number of letters to The Fiji Times during and after the election campaign commented on how useful Fiji TV's 'Question Time' series was, while the output from radio and print media has been commended as the most comprehensive of any election. See, for example, the letters page in The Fiji Times, 2 May 2006, p.10 'Question Time' and 5 May 2006, p.11 'Thanks Fiji One'.

51 Garrett, J. 1990. 'Uncertain Sequel: The Social and Religious Scene in Fiji Since the Coups'. The Contemporary Pacific, 2(1):87-111.

52 Trnka, S. 2002. 'God Only Listens to Those who Sweat. Violence, The Body and Community in Sanatan Hindu dialogues of the May 2000 coup'. Unpublished PhD Thesis. Princeton University, p.373.

53 In 1989, a group of youths attacked a Hindu temple, stating that it was their religious duty to do so. Since then the vandalism and desecration of Indian places of worship have become common. During 2005, an average of one attack a month was reported (http://www. hinduamericanfoundation.org/pdf/hhr_2005_html/fijiislands.htm).

54 The Fiji Times, 3 April 2006, p.4.

55 Bureau of Statistics. 1986. Statistical News. No. 27, p.1.

56 Voigt-Graf, C. 2002. The Construction of Transnational Spaces: Travelling Between India and Australia'. Unpublished PhD Thesis, University of Sydney, Sydney.

57 Fiji Island Bureau of Statistics estimates at 31 December 2005 http://www.spc.int/prism/ country/fj/stats/, accessed 25 July 2006.

Dean, E. \& Ritova, S. 1988. Rabuka: No Other Way. Doubleday, Moorebank. p.121.

Dean, E. \& Ritova, S. Rabuka: No Other Way. p.121. Conversation with an anonymous student at USP, 23 May 2006.

This is evidenced by expiring Indian farm leases and the significant increase in squatter settlements, for example along the Suva-Nausori corridor.

Each of the religious groups maintains a number of primary, secondary and tertiary institutions. The FML has 22 primary schools, six colleges and two junior secondary schools. The TISI Sangam has 21 primary schools, 55 secondary schools, one nursing school and one technical vocational school, and plans to establish a multi-sited technical university. The AS has six primary schools and 22 colleges. SDS has a large number of primary and secondary schools. At the time of writing, this number was unconfirmed. The APS/Fiji has 11 primary schools, eight secondary schools, eight colleges and training centres and one university.

63 The Fiji Times, 15 March 2006, p.2.

64 The Fiji Times, 17 May 2006, p.17. 
65 The Fiji Times, 15 May 2006, p.10.

66 The Fiji Times, 4 March 2006, p.13.

67 The decision to establish the University of Fiji was a joint decision between the APS/Fiji (as funding body) and academic Ganesh Chand. At the time, both Chand and the president of the APS/Fiji, Kamlesh Arya, were FLP members of parliament. The council of the University of Fiji includes a number of stakeholders drawn from post-primary education as well as prominent business leaders and renowned intellectuals. Several Indian religious organizations are also part of the council, including Arya Pratinidhi Sabha, Shri Sanatan Dharm of Fiji, FML, Gujarat Education Society, Sikh Education Society, the Andhra Sangam, the TISI Sangam, the Kabir Path Sabha. http://www.unifiji.ac.fj/about_us.htm, accessed 15 July 2006. http://www.unifiji.ac.fj/speech_chandra_adpatel2005.htm accessed 15 July 2006.

69 Interview with Kamlesh Arya, 7 July 2006.

70 Dr Arya expressed concerns about his leadership, referring to Chaudhry as having 'lost the plot' and stating that he would have to be replaced in order for the FLP to win the election. 'Bad Blood spills from Cracked Walls'. Fiji Sun, 11 March 2006, p.7.

71 The Fiji Times, 6 March 2006, p.3.

72 The Fiji Times, 13 March 2006, p.6.

73 Overall the SDL party polled approximately 3 per cent of votes in Indian Communal constituencies.

74 The SDS, TISI Sangham and Kisan Sangh entered submissions to the Sector Standing Committee on Justice, Law and Order in relation to the Promotion of Reconciliation, Tolerance and Unity Bill, 2005. All agreed that the bill would increase the potential for future coups to occur and lead to increased instability. See: http://www.parliament.gov.fj/ 